\title{
Knowledge, attitudes and practices of health-care personnel towards waste disposal management at Ain Shams University Hospitals, Cairo
}

S.A. Hakim, ${ }^{7}$ A. Mohsen ${ }^{2}$ and I. Bakr ${ }^{1}$

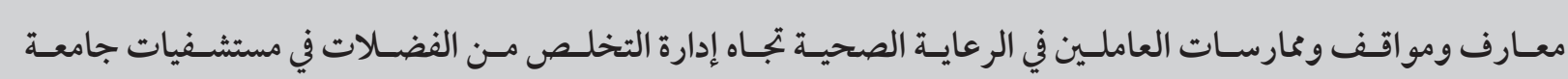

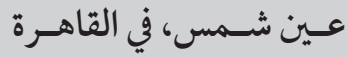

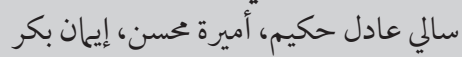

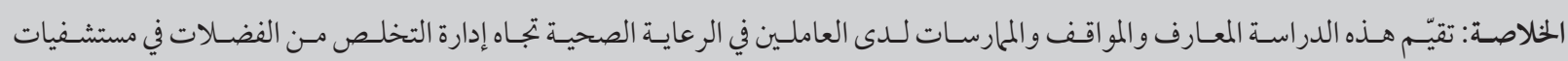

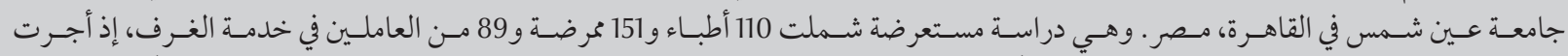

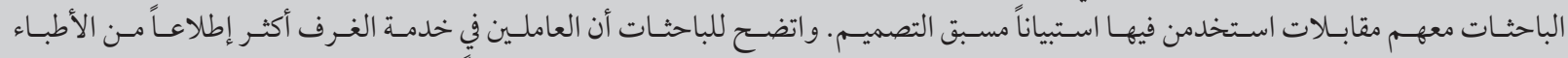

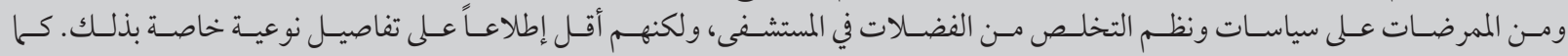

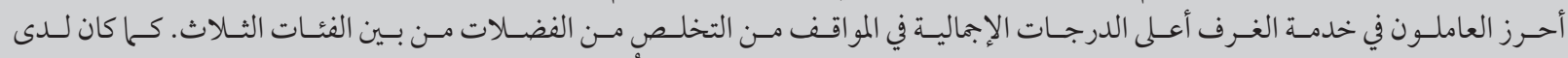

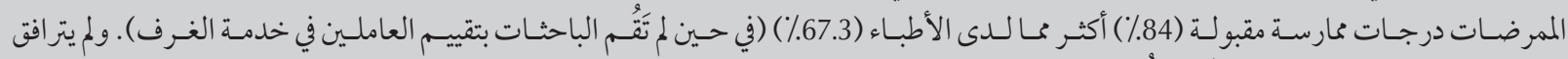

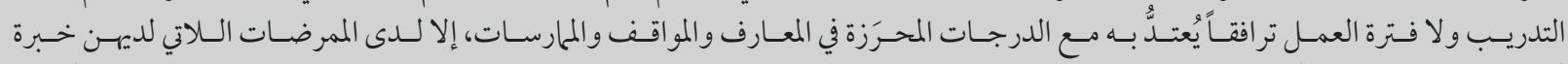

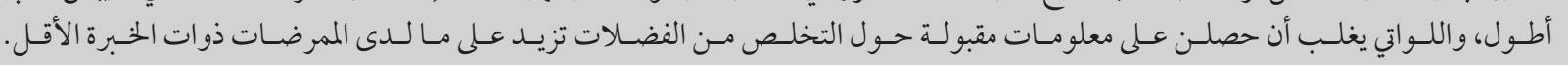

ABSTRACT This study assessed knowledge, attitudes and practices of health-care providers towards waste management at Ain Shams University Hospitals, Cairo, Egypt. In this cross-sectional study 110 physicians, 151 nurses and 89 housekeepers were interviewed using a pre-designed questionnaire. Housekeepers were significantly more knowledgeable than physicians or nurses about hospital policies and systems for waste disposal, but less so about specific details of disposal. Housekeepers also had the highest overall scores for attitudes to waste disposal among the 3 groups. Significantly more nurses had satisfactory practice scores (84.0\%) than did physicians (67.3\%) (housekeepers were not assessed). Training and duration of work experience were not significantly associated with knowledge, attitude and practice scores, except for nurses with longer work experience, who were more likely to have satisfactory knowledge about waste disposal than less experienced nurses.

Connaissances, attitudes et pratiques des membres du personnel de santé au sujet de la gestion de l'élimination des déchets au Centre hospitalier universitaire d'Ain Shams au Caire

RÉSUMÉ La présente étude a évalué les connaissances, les attitudes et les pratiques des prestataires de soins de santé au sujet de la gestion des déchets au sein du Centre hospitalier universitaire d'Ain Shams au Caire (Égypte). Dans la présente étude transversale, 110 médecins, 151 infirmières et 89 agents de ménage ont été interrogés à l'aide d'un questionnaire préétabli. Les agents de ménage avaient nettement plus de connaissances que les médecins ou les infirmières sur les politiques et les systèmes d'élimination des déchets à l'hôpital, mais moins de connaissances détaillées spécifiques sur l'élimination. Les agents de ménage ont aussi obtenu les scores généraux les plus élevés des trois groupes pour les attitudes vis-à-vis de l'élimination des déchets. Les infirmières étaient beaucoup plus nombreuses à obtenir des scores satisfaisants pour la pratique $(84,0 \%)$ que les médecins $(67,3 \%)$ (les agents de ménage n'ont pas été évalués sur ce point). La formation et le nombre d'années d'expérience n'étaient pas significativement associés aux scores pour les connaissances, les attitudes et les pratiques, sauf chez les infirmières qui avaient une expérience professionnelle plus longue. Ces dernières étaient plus susceptibles d'obtenir des scores satisfaisants pour les connaissances sur l'élimination des déchets que les infirmières moins expérimentées. 


\section{Introduction}

Biomedical waste management has recently emerged as an issue of major concern not only to hospitals, primary health-care centres and nursing home authorities but also to the environment $[1,2]$. Advances in medical facilities and the introduction of more sophisticated instruments have increased the waste generation per patient in health-care units worldwide [3]. According to the World Health Organization (WHO), high-income countries generate on average up to $0.5 \mathrm{~kg}$ of hazardous waste per hospital bed per day. Although the figure for low-income countries is only $0.2 \mathrm{~kg}$ per hospital bed per day, healthcare waste is often not separated into hazardous or non-hazardous wastes, making the real quantity of hazardous waste potentially much higher [4]. Clinical solid waste is a particular challenge in most health-care facilities of the developing world. Poor handling practices and inappropriate disposal of hospital waste is an increasing health hazard in these countries [5-7]. For example, hazardous and medical wastes may be handled and disposed of together with domestic wastes, thus creating a health risk to municipal workers, the general public and the environment [8]. In countries where efforts have been made to tackle the problem, waste disposal options are limited, and smallscale incinerators have been used as an interim solution.

Like many developing countries, Egypt struggles to enhance its hospital waste management practices. Although the Environmental Law No. 4 of 1994 was issued in order to systematize integrated hospital waste management implementation, authorities are failing to install efficient systems with respect to segregation, collection, transfer or treatment, due to weak legislative enforcement. Health-care workers in Egypt are often unaware of this legislation due to the absence of written policies and protocols. The most frequent methods of final waste disposal are incineration or autoclaving. Most general hospitals in Egypt use incineration while the majority of teaching and university hospitals use autoclaving. To our knowledge there has been only one published Egyptian study that assessed the knowledge and practice related to waste management among doctors, nurses and housekeepers in the surgical departments, at Al-Mansoura University Hospital [9]. The objective of this study therefore was to assess the knowledge, attitudes and practices (KAP) of health-care providers towards waste management at Ain Shams University Hospitals, Cairo.

\section{Methods}

\section{Study design and sample}

A cross-sectional study was conducted among 350 health-care personnel. The sample size was calculated using the Statcalc module of the Epi-Info program, version 6, with expected frequency of satisfactory KAP score 30\% +/ - 5\% at alpha error $=0.05$ and power of the test $=80 \%$. This yielded a sample size of 291 people. In order to find the association between job title and satisfactory KAP scores, the sample was adjusted and increased to 350 subjects. According to the proportion of health-care providers inside the study departments, a proportional weighted sample was taken as follows 110 physicians, 151 nurses and 89 housekeeping staff members (involved in collection and transport of hospital waste) from different departments of Ain Shams University Hospitals including the departments of general medicine, paediatrics, general surgery and obstetrics and gynaecology. The study included both males and females. This was a convenience sample; all available physicians, nurses and housekeeping staff at the time of the study were selected. Out of 368 who were invited to participate, only 12 (3.3\%) refused.
Approval from both department and central hospital administration was obtained to conduct the study. An oral consent was obtained from participants after explaining the study objectives and assuring data confidentiality. To preserve confidentiality the questionnaire was anonymous and data were kept confidential in a file that could be accessed only by the authors.

\section{Data collection}

A pre-designed questionnaire included items about the occupational background of participants (department, job title, lifetime duration of work experience and working hours per day). The questions related to KAP included 17 items. These items were developed by the authors after reviewing similar published articles. For knowledge, 6 items were included, e.g. on the existence of a waste disposal plan or strategy at the hospital, colour coding for waste disposal bags and identification of biohazard symbol. Attitudes were assessed using 6 questions, e.g. about whether they considered proper waste disposal plans a hospital priority, whether waste disposal was a team not a hospital responsibility and whether they would like to join a training programme on waste management or not. Actual practices were assessed by a participant observation checklist (5 items) concerning wearing personal protection, correct disposal of sharps and other waste, hand-washing after injection. Practices was not assessed for housekeepers as it contained observations that were not related to their job.

The questionnaire was developed in Arabic using simple local language and was tested in a pilot study with 20 persons of different job titles (physicians, nurses and housekeepers) and any required changes were made. The reliability of the questionnaire was assessed by applying reliability test using Cronbach alpha (0.73).

It was decided to deliver the questionnaire by interview as nearly a 
quarter of the housekeeping staff were illiterate or had difficultly reading and writing. Interviews were conducted by 2 of the authors with the help of 54 th-year students who were trained on interview techniques. The training was done over 2 days and included the following topics: interviewing skills, contents of the questionnaire and proper filling and coding to the answers of the questions. Emphasis was placed on using simple language for housekeepers.

The data were collected over a period of 6 weeks. The interviews were done inside the selected departments. After interviewing the participant, he/ she were observed on the same day by one of the authors in order to score the practice items in the observation checklist. The observation checklist was attached to the end of the questionnaire to facilitate the incorporation of all data for the same person in one sheet.

\section{Statistical analysis}

SPSS, version 15 was used for data entry and analysis. A summary of data was done where frequencies and percentages were calculated for qualitative data while for quantitative data, mean and standard deviations (SD) were calculated. The KAP scores were calculated as follows: satisfactory knowledge was score $\geq 4$ (range
$0-6)$; satisfactory attitude was score $\geq 4$ (range 0-6); satisfactory practice was score $\geq 3$ items practised correctly (range 0-5). The KAP scores were dichotomized to satisfactory and unsatisfactory to compare our findings with those of other studies. The chisquared test was applied to determine the relationship between the study variables and KAP scores for the 3 job groups. $P$-values were considered significant at $\leq 0.05$.

\section{Results}

The mean ages of participants were as follows: physicians 25.8 (SD 1.5) years, nurses 31.2 (SD 9.7) years and housekeepers 40.6 (SD 5.6) years. All nurses were females, while $45.5 \%$ of physicians and $37.1 \%$ of housekeepers were females (Table 1). A majority of nurses (67.5\%) had received training on waste management, compared with only $38.2 \%$ of physicians and $21.3 \%$ of housekeepers.

\section{Knowledge items}

The percentage of housekeeping staff stating that they knew about the existence of hospital and department plans for waste disposal (93.3\%) was significantly higher than that of nurses
(75.5\%) and physicians $(60.0 \%)(P<$ $0.001)$. For physicians the percentage with correct knowledge about the use of red disposal bags (60.9\%) and sharps boxes $(51.8 \%)$ and correct identification of the biohazard symbol (47.3\%) was significantly higher than among the other 2 study groups $(P<0.001)$. There was no significant difference among the 3 study groups regarding knowledge about the correct content of the black disposal bags $(P>0.05)$. By comparing the total satisfactory knowledge scores, it was found that the percentage of physicians with satisfactory knowledge scores (68.3\%) was significantly higher than among nurses (60.9\%) and housekeepers (40.4\%) (P $<0.001$ ) (Table 2).

\section{Attitude items}

The percentage of physicians agreeing that safe disposal is of utmost importance for preventing infection transmission (89.1\%) was significantly higher than among nurses $(82.1 \%)$ and housekeepers $(73.0 \%)(P<0.02)$. Moreover, the percentage of physicians agreeing that using personal protective equipment decreases the risk of contracting infection (55.5\%) was significantly higher than among nurses $(43.0 \%)$ and housekeepers $(22.5 \%)(P<0.001)$. The percentage

\begin{tabular}{|c|c|c|c|c|c|c|}
\hline Variable & \multicolumn{2}{|c|}{$\begin{array}{l}\text { Physicians } \\
(n=110)\end{array}$} & \multicolumn{2}{|c|}{$\begin{array}{l}\text { Nurses } \\
(n=151)\end{array}$} & \multicolumn{2}{|c|}{$\begin{array}{l}\text { Housekeepers } \\
\qquad(n=89)\end{array}$} \\
\hline \multicolumn{7}{|l|}{ Age (years) } \\
\hline Mean (SD) & \multicolumn{2}{|c|}{$25.8(1.5)$} & \multicolumn{2}{|c|}{$31.2(9.7)$} & \multicolumn{2}{|c|}{$40.6(5.6)$} \\
\hline Range & \multicolumn{2}{|c|}{$21-31$} & \multicolumn{2}{|c|}{$20-59$} & \multicolumn{2}{|c|}{$23-55$} \\
\hline \multicolumn{7}{|l|}{$\operatorname{Sex}($ no. \%) } \\
\hline Male & 60 & 54.5 & 0 & 0.0 & 56 & 62.9 \\
\hline Female & 50 & 45.5 & 151 & 100.0 & 33 & 37.1 \\
\hline \multicolumn{7}{|c|}{ Duration of work experience (years) (no. \%) } \\
\hline$<2$ & 43 & 39.1 & 55 & 36.4 & 23 & 25.8 \\
\hline$\geq 2$ & 67 & 60.9 & 96 & 63.6 & 66 & 74.2 \\
\hline \multicolumn{7}{|c|}{ Received training on waste disposal at the hospital (no. \%) } \\
\hline Yes & 42 & 38.2 & 102 & 67.5 & 19 & 21.3 \\
\hline No & 68 & 61.8 & 49 & 32.5 & 70 & 78.7 \\
\hline
\end{tabular}

$S D=$ standard deviation . 


\begin{tabular}{|c|c|c|c|c|c|c|c|c|}
\hline \multirow[t]{2}{*}{ Knowledge item } & \multicolumn{2}{|c|}{$\begin{array}{c}\text { Physicians } \\
(n=110)\end{array}$} & \multicolumn{2}{|c|}{$\begin{array}{l}\text { Nurses } \\
(n=151)\end{array}$} & \multicolumn{2}{|c|}{$\begin{array}{l}\text { Housekeepers } \\
\qquad(n=89)\end{array}$} & \multirow[t]{2}{*}{$\chi^{2}$-value } & \multirow[t]{2}{*}{$P$-value } \\
\hline & No. & $\%$ & No. & $\%$ & No. & $\%$ & & \\
\hline \multicolumn{9}{|l|}{ Items correctly answered } \\
\hline $\begin{array}{l}\text { Existence of department plans for waste } \\
\text { disposal }\end{array}$ & 66 & 60.0 & 114 & 75.5 & 83 & 93.3 & 35.3 & $<0.001$ \\
\hline $\begin{array}{l}\text { Existence of a hospital system for waste } \\
\text { disposal }\end{array}$ & 85 & 77.3 & 126 & 83.4 & 87 & 97.8 & 23.6 & $<0.001$ \\
\hline What to put in black disposal bags & 67 & 60.9 & 99 & 65.6 & 49 & 55.1 & 2.63 & $>0.05$ \\
\hline What to put in red disposal bags & 67 & 60.9 & 62 & 41.1 & 35 & 39.3 & 12.8 & $<0.001$ \\
\hline What to put in sharps box & 57 & 51.8 & 72 & 47.7 & 21 & 23.6 & 18.9 & $<0.001$ \\
\hline Identification of biohazard symbol & 52 & 47.3 & 52 & 34.4 & 15 & 16.9 & 20.3 & $<0.001$ \\
\hline $\begin{array}{l}\text { Satisfactory knowledge score ( } \geq 60 \% \text { items } \\
\text { correct) }\end{array}$ & 75 & 68.3 & 92 & 60.9 & 36 & 40.4 & 16.5 & $<0.001$ \\
\hline
\end{tabular}

of physicians expressing their willingness to cooperate with hospital waste management team (85.5\%) was also significantly higher than among nurses $(81.5 \%)$ and housekeepers (70.8\%) $(P<0.05)$. In contrast, the proportion of housekeeping staff agreeing that waste disposal is a team responsibility was $73.0 \%$ versus $29.8 \%$ among nurses and $28.2 \%$ among physicians and the difference was statistically significant $(P<0.001)$. The percentage of housekeepers agreeing that safe waste disposal should be a priority of the hospital (59.6\%) was also significantly higher than among nurses (35.8\%) and physicians $(40.9 \%)(P<0.001)$ Moreover, significantly more housekeepers (30.3\%) than nurses (27.8\%) and physicians (16.4\%) agreed that safe waste disposal might be a financial burden on the administrative department $(P<0.05)$. Satisfactory attitude scores were the highest among housekeeping staff (61.9\%) compared with $49.0 \%$ among nurses and 56.4\% among physicians, but this was not statistically significant (Table 3 ).

\section{Practice items}

On observation of health-care workers, significantly more nurses than physicians correctly disposed of blood-contaminated fomites (84.8\% versus $62.7 \%)(P<0.001)$ and correctly disposed of general waste $(81.5 \%$ versus $69.1 \%)(P<0.02)$. Moreover, the percentage of nurses showing satisfactory overall practice scores (84.8\%) was significantly higher than that of physicians $(67.3 \%)(P=0.001)$ (Table 4).

\begin{tabular}{|c|c|c|c|c|c|c|c|c|}
\hline \multirow[t]{2}{*}{ Attitude item } & \multicolumn{2}{|c|}{$\begin{array}{l}\text { Physicians } \\
(n=110)\end{array}$} & \multicolumn{2}{|c|}{$\begin{array}{l}\text { Nurses } \\
(n=151)\end{array}$} & \multicolumn{2}{|c|}{$\begin{array}{l}\text { Housekeepers } \\
\quad(n=89)\end{array}$} & \multirow[t]{2}{*}{$\chi^{2}$-value } & \multirow[t]{2}{*}{$P$-value } \\
\hline & No. & $\%$ & No. & $\%$ & No. & $\%$ & & \\
\hline \multicolumn{9}{|l|}{ Items agreed with } \\
\hline $\begin{array}{l}\text { Safe disposal is of utmost important to prevent } \\
\text { infection transmission }\end{array}$ & 98 & 89.1 & 124 & 82.1 & 65 & 73.0 & 8.60 & $<0.02$ \\
\hline Safe waste disposal should be a priority & 45 & 40.9 & 54 & 35.8 & 53 & 59.6 & 13.31 & $<0.001$ \\
\hline $\begin{array}{l}\text { Waste disposal is a team work not a hospital } \\
\text { responsibility }\end{array}$ & 31 & 28.2 & 45 & 29.8 & 65 & 73.0 & 53.28 & $<0.001$ \\
\hline $\begin{array}{l}\text { Efforts in safe waste disposal are a financial } \\
\text { burden on the administrative department of } \\
\text { the hospital }\end{array}$ & 18 & 16.4 & 42 & 27.8 & 27 & 30.3 & 6.39 & $<0.05$ \\
\hline $\begin{array}{l}\text { Wearing PPE decreases the risk of contracting } \\
\text { infection at the hospital }\end{array}$ & 61 & 55.5 & 65 & 43.0 & 20 & 22.5 & 22.21 & $<0.001$ \\
\hline $\begin{array}{l}\text { Likes to cooperate in hospital waste } \\
\text { management team }\end{array}$ & 94 & 85.5 & 123 & 81.5 & 63 & 70.8 & 6.97 & $<0.05$ \\
\hline Satisfactory attitude score ( $\geq 60 \%$ items correct) & 62 & 56.4 & 74 & 49.0 & 55 & 61.9 & 3.9 & 0.142 \\
\hline
\end{tabular}

NS = not significant; $P P E=$ personal protective equipment . 


\begin{tabular}{|c|c|c|c|c|c|c|}
\hline \multirow[t]{2}{*}{ Practice item } & \multicolumn{2}{|c|}{$\begin{array}{l}\text { Physicians } \\
(n=110)\end{array}$} & \multicolumn{2}{|c|}{$\begin{array}{l}\text { Nurses } \\
(n=151)\end{array}$} & \multirow[t]{2}{*}{$\chi^{2}$-value } & \multirow[t]{2}{*}{$P$-value } \\
\hline & No. & $\%$ & No. & $\%$ & & \\
\hline \multicolumn{7}{|l|}{ Items correctly performed } \\
\hline Wearing personal protective equipment & 65 & 59.1 & 106 & 70.2 & 3.48 & 0.062 \\
\hline Correct handling of blood-contaminated fomites & 69 & 62.7 & 128 & 84.8 & 16.70 & $<0.001$ \\
\hline Correct handling of sharps & 94 & 85.5 & 140 & 92.7 & 3.62 & 0.057 \\
\hline Correct handling of general waste & 76 & 69.1 & 123 & 81.5 & 5.37 & $<0.02$ \\
\hline Washing hands after injections & 63 & 57.3 & 101 & 66.9 & 2.52 & 0.112 \\
\hline Satisfactory practice score ( $\geq 60 \%$ items correct) & 74 & 67.3 & 128 & 84.8 & 11.13 & 0.001 \\
\hline
\end{tabular}

\section{Relationship with training and work experience}

On studying the variables that could affect KAP scores, it was found that duration of work experience and having ever received training on waste management were not significantly related to satisfactory scores in any of the studied domains among physicians and housekeepers, and training was not related to KAP scores of nurses $(P>0.05)$. The only significant variable was lifetime work experience among nurses; more of those who had worked $\geq 2$ years had satisfactory knowledge scores (68.7\%) than those who had worked $<2$ years $(47.3 \%)(P<0.05)($ Table 5$)$

\section{Discussion}

A key strength of this study was that this assessment of KAP related to health-care waste management gave us a unique opportunity to provide information about a topic which is lacking in our country, as we have only found one Egyptian study in the literature addressing the same objective [9]. It also helps to identify the gaps between the current KAP among the health-care workers involved in waste management and the future desired state that should be reached.

In the current study it was found that knowledge about the existence of department plans and a hospital system for waste disposal was significantly better among housekeeping staff than nurses or physicians. On the other hand, housekeeping staff in our study were less knowledgeable about specific details of disposal. This is in contrast to a study from India, which found that knowledge of the existence of biomedical waste management rules was better among doctors than nurses or paramedical staff, but that knowledge of the practical aspects of biomedical waste management was better among nurses and paramedical staff [10]. In Bangalore, India, knowledge regarding colour coding and waste segregation at source was better among nurses and laboratory staff than among doctors [11]. Our study also contrasts with the findings of another study from the north-west region of Cameroon, where most of the respondents involved in collecting, segregating, transporting and disposing clinical waste had never heard of any policy on safe clinical waste management [12]. A study in 5 government and 12 private hospitals in Sana'a, Yemen showed poor awareness among waste workers regarding medical waste handling, and a lack of differentiation between domestic and medical waste disposal [13].

Our findings showed that, overall, the percentage of physicians with satisfactory knowledge scores regarding waste disposal (68.3\%) was significantly higher than that of nurses $(60.9 \%)$ and housekeepers (40.4\%). A cross-sectional study in 8 surgical departments at AlMansoura University Hospital in Egypt showed that $36.8 \%$ of doctors, $32.1 \%$ of housekeepers and $27.4 \%$ of nurses had satisfactory overall knowledge related to waste management [9]. The high overall knowledge of doctors in our study was mainly because knowledge about specific items - the biohazard symbol and what to place in red disposal bags and sharps boxes - was significantly higher among physicians than other workers. This might be explained by the fact that more in-depth and detailed information is usually the concern of individuals with higher education and professional levels. In a study from India, it was found that knowledge about biomedical waste management rules among the technically qualified personnel such as doctors, nurses and laboratory staff was high but was low among the sanitary staff [14]. Our study also agrees with the results of a study in 2010 from Bijapur, India, in which the teaching staff of the hospital gave statistically more correct responses to questions on biomedical waste management than did non-teaching staff [15]. This is consistent with a study carried out among hospital staff in a medical college hospital in Bangalore showing that doctors and nurses had better knowledge than other staff regarding health-care waste management [11]. Moreover, it was found that doctors, nurses and laboratory technicians 


\begin{tabular}{|c|c|c|c|c|c|c|c|c|c|c|c|c|}
\hline \multirow{3}{*}{$\begin{array}{l}\text { Type of provider/work } \\
\text { practice }\end{array}$} & \multicolumn{4}{|c|}{ Knowledge } & \multicolumn{4}{|c|}{ Attitudes } & \multicolumn{4}{|c|}{ Practices } \\
\hline & \multicolumn{2}{|c|}{ Satisfactory } & \multicolumn{2}{|c|}{ Not satisfactory } & \multicolumn{2}{|c|}{ Satisfactory } & \multicolumn{2}{|c|}{ Not satisfactory } & \multicolumn{2}{|c|}{ Satisfactory } & \multicolumn{2}{|c|}{ Not satisfactory } \\
\hline & No. & $\%$ & No. & $\%$ & No. & $\%$ & No. & $\%$ & No. & $\%$ & No. & $\%$ \\
\hline \multicolumn{13}{|l|}{ Physicians } \\
\hline \multicolumn{13}{|l|}{ Received training } \\
\hline Yes & 31 & 73.8 & 11 & 26.2 & 27 & 64.3 & 15 & 35.7 & 31 & 73.8 & 11 & 26.2 \\
\hline \multirow[t]{2}{*}{ No } & 44 & 64.7 & 24 & 35.3 & 35 & 51.5 & 33 & 48.5 & 43 & 63.2 & 25 & 37.8 \\
\hline & & \multicolumn{3}{|c|}{$\chi^{2}=0.98, P>0.05$} & \multicolumn{4}{|c|}{$\chi^{2}=1.72, P>0.05$} & \multicolumn{4}{|c|}{$\chi^{2}=1.31, P>0.05$} \\
\hline \multicolumn{13}{|l|}{ Duration of work (years) } \\
\hline$<2$ & 28 & 65.1 & 15 & 34.9 & 29 & 67.4 & 14 & 32.6 & 25 & 58.1 & 18 & 41.9 \\
\hline \multirow[t]{2}{*}{$\geq 2$} & 47 & 70.1 & 20 & 29.9 & 33 & 49.3 & 34 & 50.7 & 49 & 73.1 & 18 & 26.9 \\
\hline & & \multicolumn{3}{|c|}{$\chi^{2}=0.30, P>0.05$} & \multicolumn{4}{|c|}{$\chi^{2}=3.49, P>0.05$} & \multicolumn{4}{|c|}{$\chi^{2}=2.65, P>0.05$} \\
\hline \multicolumn{13}{|l|}{ Nurses } \\
\hline \multicolumn{13}{|l|}{ Received training } \\
\hline Yes & 60 & 58.8 & 42 & 41.2 & 53 & 52.0 & 49 & 48.0 & 88 & 86.3 & 14 & 13.7 \\
\hline \multirow[t]{2}{*}{ No } & 32 & 65.3 & 17 & 34.7 & 21 & 42.9 & 28 & 57.1 & 40 & 81.6 & 9 & 18.4 \\
\hline & \multicolumn{4}{|c|}{$\chi^{2}=0.58, P>0.05$} & \multicolumn{4}{|c|}{$\chi^{2}=1.09, P>0.05$} & \multicolumn{4}{|c|}{$\chi^{2}=0.55>0.05$} \\
\hline \multicolumn{13}{|l|}{ Duration of work (years) } \\
\hline$<2$ & 26 & 47.3 & 29 & 52.7 & 26 & 47.3 & 29 & 52.7 & 44 & 80.0 & 11 & 20.0 \\
\hline$\geq 2$ & 66 & 68.7 & 30 & 31.3 & 48 & 50.0 & 48 & 50.0 & 84 & 87.5 & 12 & 12.5 \\
\hline & & & $=6.73$, & 0.05 & & & $=0.10$ & $>0.05$ & & & $x^{2}=1.51$, & 0.05 \\
\hline Housekeeping staff & & & & & & & & & & & & \\
\hline Received training & & & & & & & & & & & & \\
\hline Yes & 8 & 42.1 & 11 & 57.9 & 13 & 68.4 & 6 & 31.6 & $\mathrm{n} / \mathrm{a}$ & - & $\mathrm{n} / \mathrm{a}$ & - \\
\hline No & 28 & 40.0 & 42 & 60.0 & 42 & 60.0 & 28 & 40.0 & $\mathrm{n} / \mathrm{a}$ & - & $\mathrm{n} / \mathrm{a}$ & - \\
\hline & & & $=0.03$, & 0.05 & & & $=0.44^{\mathrm{a}}$ & $>0.05$ & & & & - \\
\hline Duration of work (years) & & & & & & & & & & & & \\
\hline$<10$ & 9 & 39.1 & 14 & 60.9 & 15 & 65.2 & 8 & 34.8 & $\mathrm{n} / \mathrm{a}$ & - & $\mathrm{n} / \mathrm{a}$ & - \\
\hline$\geq 10$ & 27 & 40.9 & 39 & 59.1 & 40 & 60.6 & 26 & 39.4 & $\mathrm{n} / \mathrm{a}$ & - & $\mathrm{n} / \mathrm{a}$ & - \\
\hline & & $\chi^{2}=0$. & $2, P>0$ & & & $\chi^{2}=0$. & $5, P>0$ & & & & - & \\
\hline
\end{tabular}

had better knowledge than sanitary staff regarding biomedical waste management in a study in Allahabad city, India [16]. A study from Mangalore, India, in 2012 found that the highest rate of correct knowledge about biomedical waste management was among nurses (61.3\%) followed by doctors (46.6\%), non-teaching staff (37.7\%) and laboratory technicians (27.9\%) [17]. A study from Nigeria revealed that the majority of all professional health workers (doctors, nurses and pharmacists) had good knowledge of collection, minimization and personal risks associated with hospital wastes (93.4\%, 94.4\% and 97.2\% respectively) [18].

Regarding the attitude of healthcare workers towards waste disposal at our hospital, it was found that, overall, more housekeeping staff had satisfactory attitude scores $(61.9 \%)$ than did nurses (49.0\%) and physicians (56.4\%), although the differences were not significant. Physicians were more likely than other workers to agree that safe disposal is of utmost importance to prevent infection transmission and that wearing personal protective equipment reduces the risk of contracting infection, and were more likely to express a willingness to cooperate in the hospital waste management team. Similar to a tertiary health-care centre in India, a positive attitude towards the need for measures for safe collection and final disposal of biomedical waste was higher among doctors (100\%) than nurses (60\%) [19]. This is in contrast to another study from India where nurses had better attitudes towards separation of waste, proper disposal, implementation of rules and cooperation in programmes than did technicians and housekeeping staff [20]. Also a study from Bangalore showed that the nurses 
had significantly more positive attitudes compared with technicians and housekeeping staff $[11]$.

On the other hand, for some items - that safe waste disposal should be a priority, that waste disposal is teamwork not a hospital responsibility, and that disposal is a financial burden on the hospital-the proportion of housekeeping staff showing approval of these items was significantly higher than that of physicians and nurses. In another study, in India, general practitioners were of the opinion that disposing biomedical waste was very expensive but could not be compromised as the waste was hazardous and improper handling could lead to spread of infectious diseases [17]. In another study in a district of Gujarat, India, it was found that $98 \%$ of the nurses and $79 \%$ of the housekeeping staff had positive attitudes versus only 59\% of the technical staff [21]. In other study in a tertiary care rural hospital in India, the majority of the sanitary stafffelt that the management of biomedical waste was not an issue at all and was purely the responsibility of the institution not an individual responsibility. They also felt that the safe management of waste was an extra burden at work [22].

We found that the practice scores of nurses were significantly higher than those of physicians ( $84.8 \%$ versus $67.3 \%$ had overall satisfactory practice). This undoubtedly reflects doctors' lack of awareness of the problem in general and their role in waste management in particular. This may be attributable to their lack of training, as fewer physicians in our study reported receiving training on proper waste management at the hospital than did nurses (38.2\% versus $67.5 \%)$. This is in agreement with a previous report showing that improper waste management was influenced more by the ignorance of local health personnel [23]. Another reason for deficient practices among doctors might be patient overload, due to the fact that Ain Shams University
Hospitals provide health care services free-of-charge to the public. Inadequate supplies or lack of interest in participating in training programmes might also contribute to deficient practices. In line with our results, another Egyptian study revealed that $18.9 \%$ of the nurses and none of the doctors had adequate waste management practices [9]. Moreover, it was found that nurses in Bangalore practised biomedical waste management significantly better than the technical and housekeeping staff [11]. The findings of another Indian study revealed that $45.4 \%$ of nurses versus only $25.8 \%$ of technicians were practising/following the biomedical waste management rules [20].

The association between duration of work experience and KAP scores among different job categories in the current study was not significant, except for the relationship between work duration and knowledge of waste management among nurses; the percentage of nurses with satisfactory knowledge scores was higher among those who had worked $\geq 2$ years than those who worked $<2$ years. In contrast to our results, another study showed no statistically significant associations between knowledge scores and nurses' age, experience or qualifications [9].

The relationship between training received on waste management and KAP scores was also explored in our study and surprisingly it was found to be non-significant across all the study groups. While this does not diminish the importance of training courses and orientation programmes on awareness about waste management, it raises an important question about the clarity of knowledge and practical skills offered in such programmes. Another study in Egypt showed that, although attendance at training programmes on waste management was the only statistically significant independent predictor of health-care staff's knowledge, no such correlation was found with actual practices [9].
Mostafa et al. suggested that most training courses and orientation programmes emphasize theoretical aspects with numerous lectures but minimal hands-on training. Moreover, training programmes should take into consideration the educational level of housekeepers, since in developing countries usually a significant proportion are illiterate $[9,24]$.

There were some limitations of the current study. The sampling method was a convenience sample. Moreover, the study was conducted in the biggest 4 departments of the university hospitals and did not include the other departments. Nevertheless, the current study successfully highlighted how in a developing country such as Egypt, despite the presence of legislation for hospital waste management implementation, proper management and disposal of waste is not yet accurately implemented by health-care workers. Our findings also revealed a gap between current knowledge of hospital waste management among health-care workers and that demanded by hospital waste management implementation policies. We recommend there should be proper and intensive training programmes regarding awareness and practices of waste disposal for all health-care staff, with continuous monitoring at regular intervals. Research must be undertaken to seal existing gaps in the knowledge about hospital waste management. The findings of this study will help to address the issue more appropriately, and inform plans for better training programmes and monitoring of biomedical waste management systems in hospitals.

\section{Acknowledgements}

The authors thank the 4th-year students who shared in data collection.

Funding: None.

Competing interests: None declared. 


\section{References}

1. Mandal SK, Dutta J. Integrated bio-medical waste management plan for Patna city, Institute of Town Planners, India Journal, 2009, 6(2):1-25.

2. Alagöz AZ, Kocasoy G. Improvement and modification of the routing system for the health-care waste collection and transportation in Istanbul. Waste Management, 2008, 28:1461-1471.

3. Radha KV, Kalaivani K, Lavanya R. A case study of biomedical waste management in hospitals. Global Journal of Health Science, 2009, 1:82-88.

4. Waste from health-care activities. Fact sheet No. 253, November 2011. World Health Organization [online factsheet] (http:// www.who.int/mediacentre/factsheets/fs253/en/, accessed 27 December 2013).

5. Hossain MS et al. Clinical solid waste management practices and its impact on human health and environment-a review. Waste Management, 2011, 31:754-766.

6. Mato RR, Kassenga GR. A study on problems of medical solid wastes in Dar es Salaam and their remedial measures. Resources, Conservation and Recycling, 1997, 21:1-16.

7. Nemathaga F, Maringa S, Chimuka L. Hospital solid waste management practices in Limpopo Province, South Africa: a case study of two hospitals. Waste Management, 2008, 28:1236-1245.

8. Da Silva CE et al. Medical wastes management in the south of Brazil. Waste Management, 2005, 25:600-605.

9. Mostafa GM, Shazly MM, Sherief WI. Development of a waste management protocol based on assessment of knowledge and practice of healthcare personnel in surgical departments. Waste Management, 2009, 29:430-439.

10. Mathew SS, Benjamin AI, Sengupta P. Assessment of biomedical waste management practices in a tertiary care teaching hospital in Ludhiana. Healthline, 2011, 2:28-30.

11. Madhukumar S, Ramesh G. Study about awareness and practices about health care waste management among hospital staff in a medical college hospital, Bangalore. Iranian Journal of Basic Medical Sciences, 2012, 3:7-11.

12. Mochungong PI, Gulis G, Sodemann M. Hospital workers' awareness of health and environmental impacts of poor clinical waste disposal in the Northwest Region of Cameroon. International Journal of Occupational and Environmental Health, 2010, 16:53-59.

13. Al-Emad AA. Assessment of medical waste management in the main hospitals in Yemen. Eastern Mediterranean Health Journal, 2011, 17:730-737.
14. Saini S, Nagarajan SS, Sarma RK. Knowledge, attitude and practices of biomedical waste management amongst staff of a tertiary level hospital in India. Journal of the Academy of Hospital Administration India, 2005, 17:1-12.

15. Yadavannavar M, Berad AS, Jagirdar P. Biomedical waste management: a study of knowledge, attitude, and practices in a tertiary health care institution in Bijapur. Indian Journal of Community Medicine, 2010, 35:170-171.

16. Mathur $\vee$ et al. Knowledge, attitude and practices about BMW management among health care personnel: a cross-sectional study. Indian Journal of Community Medicine, 2011, 36:143-145.

17. Bhasker B, Nidugala H, Avadhani R. Biomedical waste management-knowledge and practices among health care providers in Mangalore. Nitte University Journal of Health Science, 2012, 2:35-36.

18. Samuel SO, Kayode OO, Musa OI. Awareness, practice of safety measures and the handling of medical wastes at a tertiary hospital in Nigeria. Nigerian Postgraduate Medical Journal, 2010, 17:297-300.

19. Sachan R, Patel ML, Nischal A. Assessment of the knowledge, attitude and practices regarding biomedical waste management amongst the medical and paramedical staff in tertiary health care centre. International Journal of Scientific and Research Publications, 2012, 2(7):1-6.

20. Shafee M, Kasturwar N, Nirupama N. Study of knowledge, attitude and practices regarding biomedical waste among paramedical workers. Indian Journal of Community Medicine, 2010, 35:369-370.

21. Pandit NB et al. Management of bio-medical waste: awareness and practices in a district of Gujarat. Indian Journal of Public Health, 2005, 49:245-247.

22. Radha R. Assessment of existing knowledge, attitude and practices regarding biomedical waste management among the health care workers in a tertiary care rural hospital. International Journal of Health Services and Research, 2012, 2:14-19.

23. Halbachs H. Solid waste disposal in district health facilities. World Health Forum, 1994, 15:263-376.

24. Lakbala P, Lakbala M. Knowledge, attitude and practice of hospital staff management. Waste Management and Research, 2013, 31(7):729-732. 